\title{
REVISTAMARACANAN
}

Artigos

\section{Demarcações de limites e circulações nas fronteiras da Amazônia ibérica (c.1780-c.1790)}

\author{
Demarcations of boundaries and circulations on the borders of the Iberian \\ Amazon (c.1780-c.1790)
}

Carlos Augusto Bastos

Universidade Federal do Pará

carlosbastos@ufpa.br

\begin{abstract}
Resumo: A assinatura do Tratado de Santo Ildefonso, em 1777, procurou solucionar as disputas entre Portugal e Espanha nas fronteiras ultramarinas, determinando a demarcação dos limites territoriais por comissões hispano-portuguesas. Na América do Sul, a Amazônia figurava como uma das áreas de conflitos fronteiriços entre as duas coroas ibéricas. As demarcações de limites realizadas na região, entre 1780-1790, procuraram definir as soberanias territoriais hispano-portuguesas. As atividades desempenhadas pelas comissões demarcadoras, por sua vez, viabilizaram diferentes formas de circulação no espaço da fronteira, o que alimentou conflitos entre autoridades locais. Este artigo aborda as circulações de pessoas, produtos e informações nas fronteiras do vale amazônico durante as demarcações de limites promovidas pelas partidas demarcadoras luso-espanholas.
\end{abstract}

Palavras-chave: Fronteira; Amazônia; Demarcação de limites; Circulações

Abstract: In 1777, the signing of the Treaty of San Ildefonso aimed to solve the territorial disputes between Portugal and Spain in overseas borders, ordering the demarcation of boundaries by Spanish-Portuguese commissions. In South America, the Amazon was one of the areas of border conflicts between the two Iberian crowns. Between the 1780 and 1790, the demarcations of limits conducted in the region sought to define the Spanish-Portuguese territorial sovereignties. The activities performed by the commissions, in turn, made possible different forms of circulation in the border area, allowing conflicts between local authorities. This article discusses the circulations of people, goods and information at the border of the Amazon Valley during the demarcations of boundaries promoted by the Portuguese-Spanish delimiting commissions.

Keywords: Frontier; Amazon; Foundary demarcation; Circulations.

Artigo recebido para publicação em: Março de 2016

Artigo aprovado para publicação em: Julho de 2016 


\section{Introdução}

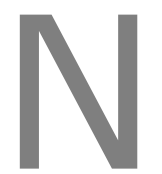

a segunda metade do século XVIII, as coroas portuguesa e espanhola buscaram assegurar seus domínios territoriais sobre o continente americano, almejando diminuir o potencial de conflitos bélicos nas zonas limítrofes lusoespanholas do Novo Mundo. Considerações dessa natureza foram essenciais para a assinatura do Tratado de Madri, em 1750, muito embora o recrudescimento das tensões imperiais tivesse levado à sua anulação em 1761 com o Tratado de El Pardo. A delimitação das soberanias territoriais, assim, permaneceu como um problema expressivo para as agendas diplomáticas das monarquias ibéricas. Nas décadas finais do Setecentos, a definição dos limites territoriais na América do Sul voltou a ser um desafio enfrentado por Portugal e Espanha. Em 1777, as duas coroas firmaram em Santo Ildefonso um tratado preliminar de limites para as possessões americanas e asiáticas, determinando a interrupção das hostilidades nas fronteiras e oficializando a intenção de resolver as pendências territoriais. Em 1778, portugueses e espanhóis assinaram o Tratado de Amizade, Garantia e Comércio. Entre os anos de 1780 e 1790, autoridades ibéricas realizaram trabalhos conjuntos de delimitação das fronteiras americanas, almejando com isso definir os espaços de seus impérios no continente. ${ }^{1}$

Segundo o Tratado de Santo Ildefonso, a demarcação de limites territoriais na América do Sul deveria ser feita por quatro divisões luso-espanholas, "cada uma delas composta de dois comissários principais, dois engenheiros, dois geógrafos e dois práticos do país". ${ }^{2}$ A chamada Quarta Partida ficou responsável pela raia fronteiriça norte da América Meridional. Muito embora a região platina representasse o principal foco de tensões e enfrentamentos entre portugueses e espanhóis no continente americano, as indefinições territoriais no vale amazônico criavam situações de desentendimentos e conflitos entre autoridades ibéricas desde o século XVII, colocando-se em discussão os direitos sobre terras, rios, populações indígenas e recursos econômicos. ${ }^{3}$ A direção da Partida Demarcadora portuguesa no extremo norte ficou a cargo de João Pereira Caldas, depois substituído pelo coronel Manoel da Gama Lobo d'Almada. A Partida espanhola, por sua vez, foi dirigida pelo coronel Francisco Requena y Herrera, que também acumulou o cargo de governador da Província de Maynas.

A comissão portuguesa, composta por cerca de 500 pessoas, reuniu-se na Capitania do Rio Negro em outubro de 1780. No ano seguinte, no mês de abril, os espanhóis, partindo de Maynas, chegaram ao lado português da fronteira, trazendo aproximadamente 300 indivíduos.

\footnotetext{
1 VIDAL, Josep Juan, MARTINEZ RUIZ, Enrique. Política Interior y Exterior de los Borbones. Madrid: Ediciones Istmo, 2001; VIVIANA TEJERINA, Marcela. "La lucha entre España y Portugal por la ocupación del espacio: una valoración alternativa del Tratado de San Ildefonso de 1777." Revista de História, n. 135, dez. 1996. p. 31-40.

2 Rio Negro, Arquivo Histórico Ultramarino (AHU), Cx.3, D.213. Ofício do encarregado das demarcações do Rio Negro e Capitão-General, João Pereira Caldas, para o Secretário de Estado da Marinha e Ultramar, Martinho de Melo e Castro. Vila de Barcelos, 21/01/1781.

3 ESPINOZA, Waldemar. Amazonía del Perú: História de la Gobernación y Comandancia General de Maynas (Hoy Regiones de Loreto, San Martín, Ucayali y Provincia de Condorcanqui). Lima: Fondo Editorial del Congreso del Perú, 2007; PORRAS BARRENECHA, Raúl. História de los Límites del Perú. Lima: Fundación M. J. Bustamante De la Fuente, 2011; REIS, Arthur Cézar Ferreira. Limites e Demarcações na Amazônia Brasileira: A Fronteira com as Colônias Espanholas (v. 2). Belém: SECULT, 1993.
} 
A vila de Ega, no rio Solimões, foi o ponto de encontro das duas partidas e funcionaria como sede das comissões demarcadoras luso-espanholas. Entre as tarefas exercidas pelas comissões demarcadoras constavam o reconhecimento dos rios limítrofes e a instalação de marcos divisórios entre os dois territórios. Essas ações tornaram possível o reconhecimento de conexões fluviais e terrestres nas zonas fronteiriças, almejando assegurar a soberania territorial das duas coroas nos confins do extremo norte sul-americano.

No final da década de 1780, as desavenças entre portugueses e espanhóis foram agravadas, na medida em que os demarcadores portugueses procuraram controlar a circulação da comissão de Requena na Capitania do Rio Negro. O encaminhamento dos trabalhos de demarcação, de fato, não perdeu de vista a preparação dos territórios limítrofes para a possibilidade de futuros conflitos armados entre portugueses e espanhóis. A expectativa da guerra permeou as relações entre as comissões demarcadoras, a despeito do compromisso mútuo, firmado em 1778, de ambas as coroas preservarem a paz em suas relações. Ao mesmo tempo, as desavenças surgidas durante as delimitações dotavam de novos elementos as disputas luso-espanholas no espaço amazônico. ${ }^{4}$ Em 1791, a comissão espanhola retirou-se de volta para a Província de Maynas, pondo fim ao trabalho conjunto das autoridades ibéricas na demarcação dos limites no espaço amazônico, questão que permaneceria inconclusa e problemática nas relações luso-espanholas. ${ }^{5}$

A longa permanência da comissão espanhola no território rio-negrino alimentou diferentes formas de contatos e circulações no espaço da fronteira, envolvendo espanhóis, portugueses e populações indígenas. Essas circulações, por um lado, revelavam-se fundamentais para a manutenção das atividades demarcatórias da região e, por outro, ocasionaram desentendimentos e conflitos entre as autoridades ibéricas. Neste artigo, objetiva-se abordar as interações e circulações de oficiais demarcadores ibéricos e outros sujeitos durante a vigência das demarcações determinadas pelo Tratado de Santo Ildefonso, entre 1780 e 1791. O espaço privilegiado de análise é a zona limítrofe entre a Capitania do Rio Negro e a Província de Maynas, ${ }^{6}$ principal espaço de atuação e convivência das comissões demarcadoras luso-espanholas no período em questão.

\footnotetext{
${ }^{4}$ BASTOS, Carlos Augusto. "A demarcação de limites sob o espectro da guerra: a Província de Maynas e a Capitania do Rio Negro no final do século XVIII." Trashumante, n. 3, 2014. p. 28-47. Simei Torres, por sua vez, destaca os conflitos envolvendo as duas partidas demarcadoras, bem como moradores indígenas, na vila de Ega. TORRES, Simei Maria de Souza. Onde os Impérios se Encontram: Demarcando fronteiras coloniais nos confins da América (1777-1791). Tese (Doutorado em História Social). PUC, São Paulo, 2011, p. 197-218.

5 TORRES, Simei Maria de Souza. Op. cit.

${ }^{6}$ A Capitania do Rio Negro, criada em 1755, era subordinada à do Pará, formando com esse, a partir de princípios da década de 1770, o Estado do Grão-Pará e Rio Negro. DOMINGUES, Ângela. "Rio Negro, Capitania de São José do." In: SILVA, Maria Beatriz Nizza da (coord.). Dicionário da História da Colonização Portuguesa no Brasil. Lisboa, São Paulo: Editorial Verbo, 1994. p. 718-722. A Província de Maynas (também conhecida como Gobernación de Maynas) data de fins do século XVI, e até princípios do século XIX esteve ligada à Audiência de Quito, tendo em vista que em 1802 essa área passou para a administração do Vice-Reino do Peru. GÓMEZ GONZÁLEZ, Sebastián. Frontera Selvática: Españoles, portugueses y su disputa por el noroccidente amazónico, siglo XVIII. Bogotá: Instituto Colombiano de Antropología e Historia - ICANH, 2014.
} 
A construção dessa investigação valeu-se principalmente da documentação produzida pelos oficiais envolvidos nas comissões demarcadoras ibéricas que atuaram no extremo norte, constituindo-se basicamente em ofícios relatando diferentes aspectos do cotidiano dos empreendimentos de reconhecimento do espaço da fronteira e delimitação da raia limítrofe. Outros aspectos do dia a dia das demarcações são constantemente mencionados nesse conjunto documental, como as dificuldades de circulação por espaços tão dilatados e pouco conhecidos. Somem-se a isso os problemas de desabastecimento e de fornecimento de materiais necessários para as tarefas que espanhóis e portugueses deveriam desempenhar nas fronteiras setentrionais (como equipamentos de medição, embarcações e outros), além dos frequentes desentendimentos que marcaram os trabalhos conjuntos dos demarcadores ibéricos. Contudo, para esse texto privilegiou-se a análise de ofícios produzidos por oficiais demarcadores espanhóis e portugueses que possibilitem, ainda que de modo fragmentário, apreender as relações de contatos e circulações estabelecidas nesses espaços limítrofes, relações essas em grande medida dinamizadas pela longa presença das partidas demarcadoras na região.

Ao longo do texto, serão consideradas as aproximações e circulações ocorridas durante os trabalhos demarcatórios e as interpretações e medidas adotadas pelas autoridades a partir de tais experiências. Primeiramente, será abordado o tema dos fluxos de pessoas entre os dois lados da fronteira. Depois, será analisada a ocorrência de trocas comerciais entre portugueses, espanhóis e populações indígenas que habitavam os dois lados da fronteira. Por fim, tratar-seá da circulação de informações políticas nas zonas fronteiriças e de sua importância na formulação dos planejamentos de delimitação e defesa do território. Conforme será analisado, as atividades desempenhadas pelas partidas demarcadoras nos limites territoriais lusoespanhóis do vale amazônico impulsionaram fluxos de sujeitos, produtos e informações. 
Figura 1

Fronteiras luso-espanholas no vale amazônico - segunda metade do século XVIII

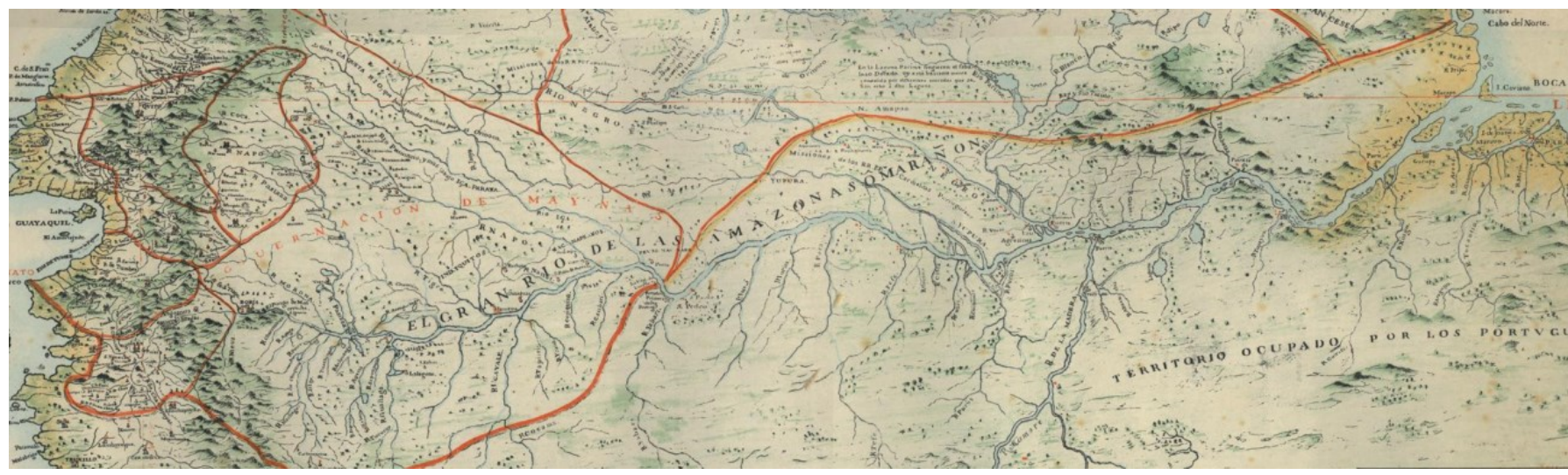

Plan Geografico del Virreinato de Santafe de Bogota Nuevo Reyno de Granada, que manifiesta su demarcación territorial, islas, ríos principales, prouincias y plazas de armas; lo que ocvpan indios barbaros y naciones extranjeras; demostrando los confines de los dos Reynos de Lima, Mexico, y establecimientos de Portvgal, sus lindantes; con notas historiales del ingreso anual de sus rentas reales, y noticias relatiuas a su actual estado civil, político y militar. Formado en servicio del Rey N[uest]ro. S[eñ]or. Por el D. D. Francisco Moreno, y Escandòn, Fiscal Protector de la Real Avdiencia de Santa Fe y

Juez Conseruador de Rents. Lo delineo D. Joseph Aparicio Morata año de 1772. Disponível em: http://www.bibliotecanacional.gov.co/recursos_user///mapoteca/fmapoteca_262_frestrepo_36/fmapotec a_262_frestrepo_36.htm. ${ }^{7}$

\section{Deslocamentos e fugas no espaço amazônico durante as demarcações de limites}

O empreendimento das demarcações de limites promoveu a movimentação de pessoas entre as partes portuguesa e espanhola da América, consistindo principalmente na movimentação de oficiais militares, soldados e trabalhadores indígenas envolvidos nos serviços demarcatórios. Na fronteira norte, houve o fluxo frequente de autoridades e soldados espanhóis, bem como de índios, da Província de Maynas para a Capitania do Rio Negro, tendo em vista que as duas partidas reuniram-se no lado português. No entanto, esse fluxo também se tornou um problema a ser enfrentado pelas autoridades ibéricas, na medida em que deu margem para o deslocamento de populações indígenas de um lado para o outro dos territórios limítrofes, ocasionando mudanças substanciais no povoamento da região. Outra questão que despertou a atenção dos demarcadores foi a fuga de soldados, motivando atritos entre os oficiais espanhóis e portugueses durante as demarcações de limites.

Os trabalhos de demarcação dependeram, em grande medida, das populações indígenas. $^{8}$ A mão de obra indígena foi intensamente utilizada nas extenuantes tarefas realizadas pelas partidas luso-espanholas, como remar as embarcações por grandes distâncias

\footnotetext{
7 Deve-se observar que essa representação cartográfica (datada de 1772, portanto anterior às demarcações luso-espanholas determinadas pelo Tratado de Santo Ildefonso) enuncia muito mais as expectativas espanholas quanto à raia fronteiriça com as possessões portuguesas na América do que propriamente o domínio territorial de Castela nessa vasta região.

8 Sobre a importância dos índios na defesa e nos trabalhos de demarcação nas fronteiras hispanoportuguesas da América, conferir: GARCIA, Elisa Frühauf. As Diversas Formas de Ser Índio: Políticas indígenas e políticas indigenistas no extremo sul da América portuguesa. Rio de Janeiro: Arquivo Nacional, 2009.
} 
transportando homens, mantimentos e equipamentos. ${ }^{9}$ Os índios das zonas fronteiriças também foram informantes privilegiados para os trabalhos de demarcação, orientando os militares ibéricos no reconhecimento do espaço que estava sendo delimitado. A manutenção dos postos militares fronteiriços, por sua vez, requeria igualmente o envio de índios para prestação de serviços, exigindo assim o deslocamento desses homens de suas vilas e lugares para áreas distantes. Além disso, a produção de mantimentos para as comissões demarcadoras dependia fundamentalmente do trabalho dos índios.

A arregimentação de mão de obra indígena para as comissões demarcadoras revelou-se um problema de grande monta. ${ }^{10} \mathrm{Em}$ diferentes documentos produzidos pelos oficiais demarcadores, protestando sobre as dificuldades para conseguir trabalhadores indígenas para as diferentes tarefas a que deveriam ser destacados, é possível perceber a recusa de muitos índios em tomar parte dos trabalhos de demarcação. Na vila de Olivença, na Capitania do Rio Negro, uma autoridade local admitiu a grande dificuldade em reunir índios para as atividades regulares da comissão demarcadora, sendo comum que eles fugissem ao desconfiar de que seriam destacados para tais serviços. ${ }^{11}$ Questões semelhantes foram vivenciadas no lado espanhol. O comissário Francisco Requena alertou, em 1789, que as exigências de deslocamento de índios de Maynas para trabalhar para a Partida espanhola estacionada no Rio Negro resultavam em "grande despoblación" no lado espanhol, com mortes e deserções de indígenas. ${ }^{12}$

Diante dos graves problemas de arregimentação de índios para as demarcações, as autoridades espanholas e portuguesas buscaram cooptar populações indígenas para que se estabelecessem nas povoações fronteiriças, a exemplo dos índios Ticuna, que habitavam a área onde se estavam definindo os limites territoriais entre Maynas e Rio Negro. ${ }^{13}$ De um modo geral, as pressões dos impérios ibéricos na área ocasionaram a mobilidade e a redistribuição dos povos indígenas. Tendo em vista a importância econômica, como também geopolítica ${ }^{14}$ dos índios no vale amazônico, as demarcações se revelaram a ocasião propícia

\footnotetext{
9 SAFIER, Neil. "Subalternidade tropical? O trabalho do índio remador nos caminhos fluviais amazônicos". In: PAIVA, Eduardo França, ANASTASIA, Carla Maria Junho. (Orgs.). O trabalho mestiço: maneiras de pensar e formas de viver, séculos XVI a XIX. São Paulo: Annablume: PPGH/UFMG, 2002. p. 427-443.

10 Deve-se observar que esse problema, presente nas demarcações de limites deliberadas pelo Tratado de Santo Ildefonso, já havia marcado o cotidiano das demarcações determinadas pelo Tratado de Madri. Para os demarcadores da década de 1750, o recurso ao trabalho indígena relevou-se um problema crucial, alimentando as críticas das autoridades lusas às missões jesuíticas e aos pretensos obstáculos que os inacianos impunham à cessão de mão de obra indígena para as demarcações de limites. Cf.: BRITO, Adilson Júnior Ishihara. Insubordinados Sertões: O Império português entre guerras e fronteiras no norte da América do Sul - Estado do Grão-Pará, 1750-1820. Tese (Doutorado em História). São Paulo, USP, 2016, p. 124-131.

${ }_{11}$ Arquivo Público do Estado do Pará (APEP), Códice 414, Doc. 2. Ofício de Custódio de Matos Pimpim ao Primeiro Comissário da Partida portuguesa. Olivença, 10/05/1784.

12 Archivo General de Índias (AGI), Santa Fe, 663B. Carta de Francisco Requena a José de Galvez. Ega, $12 / 11 / 1789$.

13 ZÁRATE BOTÍA, Carlos Gilberto. Movilidad y Permanencia Ticuna en la Frontera Amazónica Colonial del Siglo XVIII. Journal de la Societé des Américanistes, v. 1, 1998, (73-98).

14 DOMINGUES, Ângela. Quando os Índios eram Vassalos: Colonização e relações de poder no Norte do Brasil na segunda metade do século XVIII. Lisboa: Comissão Nacional para as Comemorações dos Descobrimentos Portugueses, 2000. p. 211-215 e p. 230-231.
} 
para se tentar ampliar o contingente populacional indígena de um lado da fronteira em detrimento do outro.

As demarcações de fins do século XVIII não colocaram em questão apenas as disputas por terras entre as monarquias ibéricas, mas também as disputas por habitantes para os domínios coloniais. A concorrência por vassalos indígenas nos limites da América tornou-se um ponto de atrito entre as partidas portuguesa e espanhola. Na avaliação do oficial português Henrique João Wilckens, a ocupação da fronteira com a Província de Maynas dependia do controle sobre as populações indígenas da área. Segundo Wilckens, os espanhóis intentavam atrair para seus domínios as nações indígenas que habitavam a Capitania do Rio Negro, o que deveria impelir as autoridades lusas a travar negociações com essas comunidades, conquistando o seu apoio e evitando que desfalcassem de habitantes o lado português da fronteira. ${ }^{15}$ Os demarcadores ibéricos buscaram fortalecer contatos com as nações indígenas da zona limítrofe, atraindo-as para o seu lado. Esse jogo de alianças entre autoridades e índios objetivava, por um lado, aumentar o povoamento das áreas de fronteira, tornando os índios vassalos fiéis a serviço da Coroa. Por outro lado, para os índios, essas aproximações eram igualmente interessantes, com o reconhecimento do poder das autoridades indígenas pelos funcionários coloniais e a preservação de certos direitos e vantagens das comunidades nativas. ${ }^{16}$

O estabelecimento de contatos e tratados com populações indígenas mostrava-se um aspecto imprescindível para o sucesso das demarcações, bem como de outras políticas imperiais europeias no ultramar. Em uma análise geral sobre acordos entre europeus e não europeus em diferentes experiências de expansão colonial, Salina Belmessus destaca que os tratados estabelecidos com povos nativos buscavam firmar o consentimento, o reconhecimento e a obrigação dessas populações. Nessas negociações, alguns termos mostravam-se cruciais, como o estabelecimento de acordos sobre terras, recursos e força de trabalho. Os tratados almejavam construir a legitimidade não apenas do poder europeu, mas também das populações nativas. Isso não deve ser tomado em conta sem desconsiderar, porém, o recurso à violência para o estabelecimento desses tratados, bem como os recorrentes casos em que eles serviam muito mais como um meio de imposição da autoridade colonial. ${ }^{17}$ No caso específico de negociações envolvendo autoridades luso-espanholas e populações indígenas nas fronteiras americanas, Elisa F. Garcia destaca que as alianças traçadas entre ibéricos e indígenas possuíam um caráter relacional e contextual. Nessas alianças, os índios buscavam alcançar certos benefícios quando decidiam aliar-se a portugueses ou a espanhóis (tais como

15 APEP, Códice 383, Doc. 96. Ofício de Henrique João Wilckens a João Pereira Caldas. Rio Japurá, 29/03/1782.

16 Sobre as lideranças indígenas na Amazônia e as negociações com as autoridades portuguesas no período colonial, conferir: SAMPAIO, Patrícia Maria. "Aleivosos e rebeldes": lideranças indígenas na Capitania do Rio Negro, século XVIII." In: ALMEIDA, Alfredo Wagner Berno, FARIAS JÚNIOR, Emmanuel de Almeida. (Org.). Mobilizações Étnicas e Transformações Sociais no Rio Negro. Manaus: UEA Edições, 2010. p. 126-146; ROCHA, Rafael Ale. Os oficiais índios na Amazônia Pombalina: Sociedade, Hierarquia e Resistência (1751-1798). Dissertação (Mestrado em História Social). UFF, Niterói, 2009.

17 BELMESSOUS, Salina (ed.). Empire by Treaty: Negotiating European Expansion, 1600-1900. New York: Oxford University Press, 2015. p. 12. 
apoio militar contra grupos indígenas rivais, manutenção de trocas comerciais, salvaguarda de seus territórios frente a agressões de colonos). ${ }^{18}$ Esse jogo de alianças foi particularmente evidente nas zonas de fronteira do século XVIII, onde as rivalidades imperiais pela incorporação de territórios e vassalos envolveram amplos contingentes de comunidades indígenas, as quais se tornaram participantes de grande importância nessas disputas. ${ }^{19}$

As negociações travadas entre demarcadores e índios deram margem para desentendimentos entre os comissários de Espanha e de Portugal. Colocava-se em questão a legitimidade dessas aproximações, com acusações recíprocas de que se estava desfalcando de habitantes um lado da fronteira em benefício do outro. Esses protestos foram recorrentes entre as autoridades espanholas. Segundo o primeiro comissário espanhol, as incursões dos portugueses, principalmente nos rios Putumayo e Japurá, visavam deslocar indígenas para a América lusa, tornando-se esses rios verdadeiras zonas de fornecimento de índios para o Estado do Grão-Pará e Rio Negro. ${ }^{20}$ Ainda no rio Putumayo, os portugueses estabeleceram um destacamento que visaria, segundo os comissários demarcadores espanhóis, impedir a

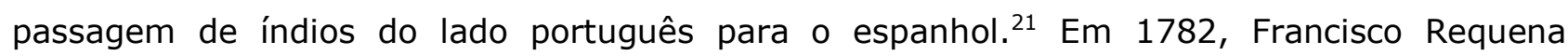
protestou junto ao comissário da Partida Portuguesa, Teodósio Constantino de Chermont, com relação aos contatos estabelecidos pelos portugueses com os índios da nação Taboca, convencendo-os a saírem do lado espanhol para as terras luso-americanas. Em sua resposta ao comissário espanhol, argumentou Chermont que, "na realização das demarcações, se [realizava] o real indulto da liberdade de cada um povoar onde conveniente Ihe [fosse]", principalmente no caso de populações indígenas que habitavam terras que seriam divididas entre as duas coroas no processo de demarcação. ${ }^{22} \mathrm{Na}$ avaliação de Requena, contudo, nenhum deslocamento de comunidades indígenas poderia ser realizado sem que antes se definissem os limites entre os dois domínios, processo ainda em curso naquele momento. ${ }^{23}$

Os atritos com relação aos direitos de contatos e deslocamento de populações indígenas de um lado para outro dos domínios hispano-portugueses no vale amazônico constituiu um recorrente ponto de conflito entre as autoridades responsáveis pelas demarcações. Para além dessa questão, os oficiais demarcadores das duas partidas também tiveram de lidar com os problemas causados pela fuga de escravos e desertores na fronteira. O tratado de limites de 1777 estabelecia regras para a devolução de soldados e cativos fugitivos. No entanto, as fugas

\footnotetext{
18 Ainda sobre as expectativas indígenas na celebração de acordos com espanhóis e portugueses nas fronteiras americanas, cf. HERZOG, Tamar. Frontiers of Possession: Spain and Portugal in Europe and the Americas. Cambridge/London: Harvard University Press, 2015. p. 106-107.

19 GARCIA, Elisa Frühauf. As Diversas Formas de Ser Índio. Op. cit., p. 227-235. Sobre as negociações entre autoridades ibéricas e ameríndios na fronteira oeste colonial, cf.: CARVALHO, Francismar Alex Lopes de. Lealdades Negociadas: Povos indígenas e a expansão dos Impérios ibéricos nas regiões centrais da América do Sul (segunda metade do século XVIII). Tese (Doutorado em História). São Paulo, FFLCH-USP, 2012, (capítulo 6).

${ }^{20}$ AGI, Santa Fe, 663B. Carta de Francisco Requena a José de Galvez. Ega, 30/01/1781.

21 AGI, Santa Fe, 663B. Carta de Francisco Requena a José de Galvez. Ega, 20/06/1783.

22 APEP, Códice 399, Doc. 5. Ofício de Teodósio Constantino de Chermont a Francisco Requena. Ega, 30/12/1782.

23 Rio Negro, AHU_ACL_CU_020, Cx.7, D.304. Ofício do encarregado das demarcações do Rio Negro e Capitão-General, João Pereira Caldas, para o Secretário de Estado da Marinha e Ultramar, Martinho de Melo e Castro. Vila de Barcelos, 13/02/1784.
} 
de um lado para outro dos domínios ibéricos na América foram recorrentes. ${ }^{24}$ No caso das deserções de soldados, além do enfraquecimento local da presença militar, elas colocavam em risco a defesa das regiões fronteiriças, na medida em que esses fugitivos poderiam fornecer dados estratégicos sobre os territórios vizinhos.

Um exemplo dessa circulação de informações estratégicas promovida por desertores pode ser tomado a partir do caso do soldado Gervazio Leclere. Nascido em Liège e servindo à República da Holanda na Fortaleza de Essequibo, Leclere havia desertado primeiramente para as terras fronteiriças da Província de Guayana, Capitania Geral da Venezuela. Leclere fugiu depois para a Capitania do Rio Negro, onde, ao ser detido pelos portugueses no rio Branco, forneceu a eles informações sobre as forças espanholas estacionadas no rio Uraricuera - disse que eram 15 soldados, comandados por "um sargento preto", e que careciam de víveres na área. ${ }^{25}$ No ano de 1790 , um sargento e um soldado desertados da comissão demarcadora espanhola para a Capitania do Pará deram informações aos portugueses sobre o comércio de salsa praticado pela Partida de Requena no território da Capitania do Rio Negro. ${ }^{26}$ Dois anos depois, desertores espanhóis, vindos de Maynas, relataram aos oficiais lusitanos sobre a presença militar espanhola no rio Javari, na fronteira com os domínios portugueses. ${ }^{27}$ Os espanhóis também receberam em suas fileiras desertores do lado português. Em 1785, o soldado português Clemente de Souza fugiu para o quartel da Partida espanhola, após matar a punhaladas "a outro soldado seu companheiro e amigo por nome Bernardino José". O soldado Clemente implorou a Francisco Requena que intercedesse por ele, solicitando às autoridades militares portuguesas que sua pena fosse comutada de capital por outra mais branda, o que o primeiro comissário fez quando devolveu o soldado à Partida portuguesa. ${ }^{28}$

No entanto, a devolução de desertores portugueses não foi uma prática que sempre caracterizou a atitude dos oficiais demarcadores espanhóis nessa questão. Em certas ocasiões, Francisco Requena e seus subordinados demonstravam mais empenho em evitar o retorno de

\footnotetext{
${ }^{24}$ Sobre a deserção de soldados no Grão-Pará do século XVIII, conferir: NOGUEIRA, Shirley Maria Silva. Razões para desertar: institucionalização do exército no estado do Grão-Pará no último quartel do século XVIII. Dissertação (Mestrado em Planejamento do Desenvolvimento). UFPA/NAEA, Belém, 2000. A respeito de fuga de escravos na região, conferir: BEZERRA NETO, José Maia. Escravidão Negra no GrãoPará, Séculos XVII-XIX. Belém: Editora Paka-Tatu, 2001; GOMES, Flávio dos Santos. A Hidra e os Pântanos: Mocambos, quilombos e comunidades de fugitivos no Brasil (séc. XVII-XIX). São Paulo: Ed. Unesp, Ed. Polis, 2005.

25 Primeira Comissão Demarcadora de Limites (PCDL), Arquivo Ponte Ribeiro, A-14: "Sobre as diversas perguntas feitas ao estrangeiro, que foi conduzido a esta vila do Rio Branco".

26 Rio Negro, AHU_ACL_CU_020, Cx.16, D.590. Ofício do governador do Rio Negro, Coronel Manuel da Gama Lobo d'Almada, para o Secretário de Estado da Marinha e Ultramar, Martinho de Melo e Castro. Vila de Barcelos, 06/12/1790.

27 APEP, Códice 493, Doc. 02. Ofício de Manoel da Gama Lobo d'Almada para Martinho de Melo e Castro. Fortaleza da Barra do Rio Negro, 10/01/1792.

28 ANRJ, Cx.474, pacote 01 (1764-1815). Fundo: Vice-Reinado. Ofício de João Pereira Caldas a Martinho de Souza e Albuquerque. Barcelos, 03/12/1785; Ofício de João Batista Mardel a João Pereira Caldas. Ega, 24/10/1785; Ofício de João Batista Mardel a Francisco Requena. Ega, 21/10/1785; Ofício de Francisco Requena a João Batista Mardel. Ega, 22/10/1785; Resposta de João Batista Mardel a Francisco Requena. Ega, 22/10/1785; Resposta de Francisco Requena a João Batista Mardel. Ega, 22/10/1785; Resposta de João Batista Mardel a Francisco Requena. Ega, 22/10/1785; Ofício de José Antonio Carlos de Avellar a João Pereira Caldas. Barcelos, 25/11/1785; Ofício de Francisco Requena a José Antonio Carlos de Avellar. Ega, 26/10/1785; Resposta de José Antonio Carlos de Avellar a Francisco Requena. Barcelos, $19 / 11 / 1785$.
} 
desertores para o lado português da fronteira. Exemplo disso foi o caso do soldado Tomás de Aquino, que fugiu com sua família de Tabatinga para o lado espanhol limítrofe. Pouco tempo depois, o português e seu filho estavam trabalhando para os demarcadores espanhóis. Quando Tomás de Aquino fez menção de se reapresentar para seus antigos superiores, Requena o impediu. ${ }^{29}$ No ano de 1791, outros soldados portugueses desertaram de Tabatinga para a Província de Maynas, o que levou as autoridades da Partida portuguesa a pedir auxílio de Requena na captura dos fugitivos. Contudo, os desertores não apenas não foram restituídos, como também foram remetidos à cidade de Quito, bem longe da fronteira com os domínios portugueses. ${ }^{30}$ Quando esteve em Tabatinga, em 1792, o alferes espanhol Don Juan Salinas havia tentado seduzir "com grandes promessas" os soldados que serviam no posto fronteiriço; alguns foram convencidos a desertar, seguindo "com todo o cuidado até Quito" e recebendo cada desertor a quantia de seis pesos como recompensa por sua decisão de fugir para as terras hispano-americanas. ${ }^{31}$

A despeito das orientações diplomáticas sobre a devolução mútua de fugitivos durante as demarcações, ${ }^{32}$ as autoridades demarcadoras relutavam em realizar a entrega desses sujeitos, entendendo que seria mais vantajoso ou prudente mantê-los dentro de seus domínios. Argumentos dessa natureza foram apresentados, em 1784, pelo oficial português João Batista Mardel a João Pereira Caldas, primeiro comissário luso. Naquela oportunidade, havia fugido de Maynas um mulato de nome Agostinho, o qual os espanhóis haviam comprado dos portugueses na cidade de Belém. Esse escravo dominava os ofícios de sapateiro e de carpinteiro e era empregado pelos espanhóis no trabalho de fabricação de canoas. Mardel informou a Pereira Caldas que não havia impedido a fuga do mulato: "antes dela lhe dei tempo para que chegasse à Fortaleza da Barra [do Rio Negro]". Segundo Mardel, não seria conveniente que os espanhóis tivessem entre eles um escravo que conhecia bem o território do Grão-Pará e do Rio Negro. O oficial português também não havia restituído a Francisco

\footnotetext{
29 Rio Negro, AHU_ACL_CU_020,CX.5, D.255. Ofício do encarregado das demarcações do Rio Negro e Capitão-General, João Pereira Caldas, para o Secretário de Estado da Marinha e Ultramar, Martinho de Melo e Castro. Vila de Barcelos, 03/02/1783.

30 APEP, Códice 493, Doc. 04. Ofício de Manoel da Gama Lobo d'Almada para Martinho de Melo e Castro. Fortaleza da Barra do Rio Negro, 11/01/1792. Conferir também: Rio Negro, AHU_ACL_CU_020,Cx.16, D.620. Ofício do Governador do Rio Negro, Coronel Manuel da Gama Lobo d'Almada, para o Secretário de Estado da Marinha e Ultramar, Martinho de Melo e Castro. Fortaleza da Barra do Rio Negro, 10/01/1792.

31 APEP, Códice 482, Doc. 46. Ofício de Henrique João Wilckens a Manoel da Gama Lobo d'Almada. Tabatinga, 19/11/1791.

32 As determinações sobre devolução de fugitivos durante as demarcações constam no artigo $19^{\circ}$ do Tratado de 1777: "en dicho espacio por toda la frontera se evite el asilo de ladrones o asesinos, los gobernadores fronterizos tomarán también de común acuerdo las providencias necesarias, concordando el medio de aprehenderlos y de extinguirlos con imponerles severísimos castigos. Asimismo, consistiendo las riquezas de aquel país en los esclavos que trabajan en su agricultura, convendrán los propios gobernadores en el modo de entregarlos mutuamente en caso de fuga, sin que por pasar a diverso dominio consigan libertad, y sí solo la protección para que no padezcan castigo violento, si no lo tuvieren merecido por otro crimen." "Tratado Preliminar de Límites en la América Meridional, Ajustado entre las Coronas de España y Portugal, Firmado en San Ildefonso en el 1 de Octubre de 1777." BEERMAN, Eric. Francisco Requena. La Expedición de Límites: Amazonía, 1779-1795. Madrid: Compañía Literaria, 1996. p. 85.
} 
Requena um soldado desertor castelhano, determinando que ele fosse mantido preso juntamente com um índio espanhol que fugira de sua Partida. ${ }^{33}$

Os conflitos e as desconfianças que marcaram a convivência entre as partidas demarcadoras espanhola e portuguesa na Capitania do Rio Negro criavam situações e possibilidades para as fugas através das fronteiras de soldados, indígenas e cativos de origem africana. Ao mesmo tempo que o cotidiano desses sujeitos era influenciado pelas disputas que opunham os impérios ibéricos nas zonas limítrofes da América, essas mesmas disputas poderiam ser manejadas por esses homens com o objetivo de alcançar uma situação melhor, o que poderia significar tanto escapar de punições, alcançar pequenas regalias ou mesmo assegurar suas liberdades. O caráter transitório da vida cotidiana na colônia, ${ }^{34}$ com deslocamentos periódicos de homens e mulheres pelo território, era, por sua vez, acentuado pelas pressões e estratégias nas quais os moradores das fronteiras se viam envolvidos durante os trabalhos de demarcação.

\section{As partidas demarcadoras e as trocas comerciais}

Uma das formas de circulação vigentes nas áreas fronteiriças da América ibérica era o comércio, principalmente o ilegal. O contrabando na fronteira luso-espanhola figurava como fonte de preocupações das coroas ibéricas durante as demarcações. No documento do tratado de 1777, havia a orientação aos chefes das comissões demarcadoras para coibir as práticas de contrabando durante os trabalhos de delimitação dos limites (proibição que, ressalte-se, já havia sido enunciada no Tratado de Madri). ${ }^{35}$ Essa forma de comércio constituía parte das tensões entre as monarquias europeias, na medida em que o contrabando indicava os limites dos poderes imperiais em controlar as relações mercantis nas colônias. Ao mesmo tempo, porém, a existência desse tipo de comércio relacionava-se com as dificuldades de abastecimento vivenciadas pelas sociedades coloniais, de modo que o contrabando viabilizava a circulação de produtos e a própria reprodução da sociedade em várias partes da América. ${ }^{36}$

No período em questão, as relações comerciais oficialmente estabelecidas entre portugueses e espanhóis na fronteira norte giraram em torno principalmente do abastecimento das partidas de demarcação. Sustentar o trabalho das partidas implicava alimentar e equipar os homens que delas faziam parte, o que exigia, por sua vez, a manutenção de trocas comerciais capazes de abastecer os oficiais, soldados e índios que serviam às coroas ibéricas

\footnotetext{
33 APEP, Códice 402, Doc. 02. Ofício de João Batista Mardel a João Pereira Caldas. Ega, 22/07/1784.

34 NOVAIS, Fernando A. "Condições da privacidade na colônia." In: NOVAIS, Fernando A., SOUZA, Laura de Mello e. (Org.). História da Vida Privada no Brasil, v. 1: Cotidiano e vida privada na América portuguesa. São Paulo: Companhia das Letras, 1997. p. 13-39.

35 "Cualquier individuo de las dos naciones que se aprehendiere haciendo el comercio de contrabando con los individuos de la otra, será castigado en su persona y bienes impuestas por las leyes de la nación que hubiere aprehendido." "Tratado Preliminar de Límites en la América Meridional, ajustado entre las Coronas de España y Portugal, firmado en San Ildefonso el 1 de Octubre de 1777." Apud BEERMAN, Eric. Op. cit., p. 84.

36 ROMANO, Ruggiero. Mecanismos y elementos del sistema económico colonial americano, siglos XVIXVIII. México: Fondo de Cultura Económica, 2004. p. 279-299.
} 
nas atividades de delimitação. O empreendimento político e militar das demarcações estimulou o estabelecimento de trocas mercantis, impulsionando a circulação de produtos no espaço fronteiriço luso-espanhol.

Havia dificuldades entre os espanhóis destacados no lado português da fronteira em manter um fornecimento regular e em quantidade suficiente de produtos a partir da Província de Maynas. Ao comparar o abastecimento de sua Partida com a portuguesa, Francisco Requena destacou os grandes empecilhos que os espanhóis tinham de enfrentar, encontrandose eles impossibilitados de conseguir das sedes administrativas da América espanhola o envio regular de mantimentos. Na visão do comissário espanhol, as longas e acidentadas distâncias que separavam a Partida espanhola das principais cidades hispano-americanas contribuíam também para encarecer o preço dos alimentos. ${ }^{37}$

Tendo em vista as dificuldades para abastecer sua Partida, Requena tomou a iniciativa de firmar, em 1785, um contrato com o comerciante e capitão de auxiliares do Rio Negro, José Antônio Freire Évora. Freire Évora era um dos poucos homens brancos tidos como ricos na capitania, destacando-se como proprietário de escravos e como um dos devedores da extinta Companhia Geral de Comércio do Grão-Pará e Maranhão. ${ }^{38}$ Portanto, José Antonio Freire Évora era um dos sujeitos mais abastados e influentes da sociedade rio-negrina da segunda metade do Setecentos, e sua posição privilegiada no comércio local certamente foi importante para que Requena o tivesse escolhido para firmar o contrato. Pelo contrato, Freire Évora deveria comprar mantimentos para a Partida espanhola preferencialmente com os administradores da extinta Companhia de Comércio do Grão-Pará e Maranhão, na cidade de Belém, e receberia uma porcentagem pela intermediação. ${ }^{39}$ Esse contrato, porém, não sanou os problemas vivenciados pela Partida espanhola. No início de 1786, um oficial espanhol reclamou do fato de os comerciantes portugueses contratados não terem remetido farinha, ${ }^{40}$ gênero indispensável para a alimentação da tropa, o que indica a persistência dos problemas de abastecimento.

Abastecer de maneira adequada a Partida mostrava-se um item primordial para o sucesso da expedição espanhola no Rio Negro. Para tanto, os espanhóis buscaram sustentar trocas comerciais com as populações nativas da capitania, e mesmo com soldados portugueses, visando comprar os mantimentos necessários para o sustento das expedições demarcadoras. O fornecimento de produtos para os homens que trabalhavam na demarcação, contudo, tornou-se um terreno de conflito entre espanhóis e portugueses na Capitania do Rio Negro. As rivalidades e desconfianças que subsistiam entre as duas partidas pesaram nessa questão, ao passo que os portugueses, segundo os espanhóis, empenhavam-se em criar

37 APEP, Códice 392, Doc. 37. Ofício de Francisco Requena a Teodósio Constantino Chermont. Ega, $12 / 03 / 1783$.

38 SAMPAIO, Patrícia Maria Melo. Espelhos Partidos: etnia, legislação e desigualdade na Colônia - Sertões do Grão-Pará, c. 1755-c.1823. Tese (Doutorado em História). Instituto de Ciências Humanas e Filosofia, Universidade Federal Fluminense, Niterói, 2001, p. 70.

39 Rio Negro, AHU, Cx.10, D.391. Ofício do encarregado das demarcações do Rio Negro e capitão-general, João Batista Caldas, para o secretário de Estado da Marinha e Ultramar, Martinho de Melo e Castro. Barcelos, 28/09/1785.

40 Archivo Histórico de Límites del Perú, LEB3-37. Ofício enviado ao Presidente da Audiencia de Quito. Ega, 30/01/1786. 
obstáculos para esse comércio, prejudicando assim os trabalhos de Requena e seus subordinados. Em ofício enviado ao tenente-coronel João Batista Mardel, membro da Partida lusa, o primeiro comissário espanhol acusou os oficiais portugueses de dar ordens a seus subordinados para suspender a venda de mantimentos para os espanhóis, o que havia obrigado Requena a mandar parte de seus homens de volta para Maynas, visto que não dispunha de mantimentos suficientes para alimentar todos eles. ${ }^{41}$

Nessa situação, o contrabando entretido com os moradores do Rio Negro surgia como alternativa para o abastecimento da Partida espanhola. Segundo afirmativa apresentada por alguns oficiais espanhóis, o comissário português teria proibido o comércio de víveres com os espanhóis, principalmente de farinha, objetivando criar obstáculos para a permanência da Partida espanhola na Capitania do Rio Negro. Mesmo assim, os espanhóis conseguiam comprar farinha graças a alguns índios e soldados portugueses que os procuravam sigilosamente à noite para vender o produto. ${ }^{42} \mathrm{Em}$ outra oportunidade, um religioso português procurou Requena para propor um modo de abastecer sua Partida sem que os oficiais portugueses soubessem. Pela proposta do religioso, os espanhóis atracariam o barco pesqueiro da Partida na povoação onde ele atuava, deixando na embarcação o valor referente aos produtos que desejavam comprar. O religioso iria discretamente ao barco, recolheria o pagamento e deixaria os mantimentos requisitados pelos espanhóis, evitando-se, assim, a repressão por parte do comissário português. ${ }^{43} \mathrm{O}$ contrabando, dessa forma, respondia às necessidades primárias de manutenção dos demarcadores espanhóis no território da Capitania do Rio Negro, contando com a participação no comércio ilícito de militares e moradores do lado português.

Coibir o entrelaçamento de trocas comerciais entre autoridades da Capitania do Rio Negro e oficiais espanhóis foi uma das preocupações recorrentes dos dirigentes da Partida portuguesa, na medida em que essas aproximações significavam um atentado à soberania lusa naquela fronteira. No entendimento dos portugueses, as autoridades locais envolvidas em franco comércio com os espanhóis poderiam agir mais de acordo com seus interesses privados do que com o princípio de defesa do território e de conservação da soberania lusa. Desconfiança dessa natureza pesou sobre o diretor da vila de Fonte Boa, no rio Solimões, sobre quem se realizou uma devassa para investigar as suspeitas de que ele ajustara "algum negócio" com Don Joaquin de Bustos, oficial da Partida demarcadora espanhola. Corria o boato de que o diretor mantinha "amizade íntima" com Bustos, o que teria facilitado ao espanhol

41 Rio Negro, AHU_ACL_CU_020_Cx.8, D.343. Ofício do encarregado das demarcações do Rio Negro e capitão-general, João Batista Caldas, para o secretário de Estado da Marinha e Ultramar, Martinho de Melo e Castro. Barcelos, 02/09/1784.

42 AGI, Santa Fe, 663B. Carta firmada por Francisco Requena y Herrera, Felipe de Arechua y Sarmiento, Miguel Hernández Bello, Don Mariano Bravo, Gaspar de Santisteban, José Mazorra, y José Antonio Villalobos. Ega, 17/07/1784.

43 "[...] el único medio que se proporcionaba [para realizar a venda] era que se dejasen dichos víveres en nuestro pesquero, donde se pusiese el dinero correspondiente a su satisfacción y paga, guardando siempre el mayor silencio y posible recato, a fin de que no lo entendiese el comisario portugués, porque castigaría crudamente a los vendedores, y aun perdería ciertamente a dicho eclesiástico si llegase a comprender este trato." AGI, Santa Fe, 663B. Carta firmada por Francisco Requena y Herrera, Felipe de Arechua y Sarmiento, Miguel Hernández Bello, Don Mariano Bravo, Gaspar de Santisteban, José Mazorra, y José Antonio Villalobos. Ega, 17/07/1784. Não há informações no documento quanto ao nome do religioso e nem da localidade onde seriam realizadas as trocas comerciais. 
estabelecer-se com seus homens em Fonte Boa, bem como adquirir canoas, extrair madeiras, plantar roças na povoação e organizar uma expedição espanhola ao Içá, rio cujos limites encontravam-se em disputa entre as duas partidas. ${ }^{44}$

Os oficiais portugueses procuravam acompanhar com cuidado as práticas comerciais mantidas pelos espanhóis. O interesse cada vez maior por parte dos habitantes da Capitania do Rio Negro em fazer negócios com a Partida espanhola seria, na avaliação dos membros da Partida portuguesa, a aquisição da prata produzida na América espanhola. Como observou com ironia um oficial português, os habitantes do Rio Negro vivenciavam a "felicidade de nadarem [nos] rios de prata que [emanavam]" da Partida espanhola. ${ }^{45}$ Contudo, a oferta de prata gerava igualmente a especulação sobre os produtos que eram vendidos à Partida espanhola. Assim, quando Requena tentou comprar no Rio Negro canoas para sua Partida, mostrou-se indignado com o preço abusivo das embarcações que lhe foram oferecidas pelos moradores. ${ }^{46}$

No entanto, o controle do comércio na fronteira não era um ponto de preocupação somente entre as autoridades portuguesas. Para os espanhóis, importava barrar a incursão de canoas do lado português da fronteira na Província de Maynas. Essas entradas eram motivadas pela busca de produtos extrativos, os quais eram contrabandeados para a América lusa. Os rios das zonas limítrofes tornaram-se pontos de exploração pelos portugueses de produtos como cacau, salsaparrilha e ovos de tartaruga (dos quais se produzia a "manteiga de tartaruga" $\left.{ }^{\prime 47}\right)$. Nessas incursões, os portugueses mantinham contatos comerciais com as populações indígenas locais, o que contribuía para alimentar as tensões entre os representantes das duas coroas no decorrer das demarcações. Ressalte-se que, ao longo do século XVIII, o comércio passou a ser considerado pelos condutores do reformismo espanhol um meio de civilizar os índios e atraí-los para a soberania de Castela e para a fé católica. ${ }^{48}$ Desse modo, a presença de portugueses comerciando com índios nas fronteiras espanholas do vale amazônico contrariava objetivos políticos centrais do Império espanhol para o continente.

Entre os oficiais portugueses, existia ainda a suspeita de que o primeiro comissário espanhol estivesse diretamente envolvido em contrabandos, conseguindo ganhos substanciais

\footnotetext{
44 Rio Negro, AHU_ACL_CU_020, Cx.5, D.255. Oficio do encarregado das demarcações do Rio Negro e Capitão-General, João Pereira Caldas, para o Secretário de Estado da Marinha e Ultramar, Martinho de Melo e Castro. Vila de Barcelos, 03/02/1783.

45 APEP, Códice 416, Doc. 12. Ofício de João Batista Mardel a Francisco Requena. Ega, 16/07/1784.

46 APEP, Códice 383, Doc. 20. Ofício dirigido a João Pereira Caldas. Ega, 20/01/1782.

47 Segundo Alexandre Rodrigues Ferreira, a manteiga produzida a partir dos ovos de tartaruga servia "para temperar as comidas e fritar peixe, para as luzes domésticas, e para se incorporar com o breu, quando fazem para calafetarem as canoas". FERREIRA, Alexandre Rodrigues. Viagem Filosófica pelas Capitanias do Grão-Pará, Rio Negro, Mato Grosso e Cuiabá. Rio de Janeiro: Conselho Federal de Cultura, 1972. p. 27.

$48 \mathrm{Na}$ avaliação de David J. Weber, essa reorientação política da Coroa espanhola com relação aos meios de atrair os índios era também uma resposta prática aos desafios e limites enfrentados pela Espanha no quadro das rivalidades imperiais. Nas palavras do autor: "Hasta cierto punto, este énfasis de finales del siglo XVIII en el comercio com el instrumento preferido para el control de los indios independientes constituía una respuesta práctica de España a su capacidad, cada vez menor, para pelear contra los indígenas americanos en un momento en el que sus guerras en Europa consumían sus recursos". Não se pode desconsiderar, ainda segundo Weber, o caráter econômico presente nessa mudança: "El nuevo énfasis en el comercio también reflejaba un interés más amplio de los Borbones en hacer más rentables sus colonias americanas". WEBER, David J. Bárbaros. Los españoles y sus salvajes em la Era de la Ilustración. Barcelona: Crítica, 2007. p. 269.
} 
com a venda de produtos no Rio Negro. Escrevendo para João Pereira Caldas no ano de 1784, o tenente-coronel João Batista Mardel afirmou que o primeiro comissário espanhol lucrava com a venda de cacau, salsaparrilha e com a compra de outras mercadorias. ${ }^{49}$ Mardel encaminhou essas acusações diretamente a Francisco Requena, afirmando que a falta de mantimentos enfrentada pelos espanhóis explicava-se pelo fato de Requena enviar canoas a Belém não para a compra de mantimentos para a sua Partida, mas sim para a venda de produtos para seu comércio particular. ${ }^{50}$

Os supostos negócios privados do comissário Requena também despertaram a atenção no lado espanhol da fronteira. Suspeitava-se que o contrabando alimentado pela Partida espanhola em terras luso-americanas estivesse tomando proporções alarmantes, desviando a comissão de seus objetivos primordiais. Em dezembro de 1789, Don Ventura Díaz del Castillo, presbítero da cidade de Quito, encaminhou à Presidência da Audiência uma representação na qual acusava Francisco Requena de promover o contrabando. Sustentava Díaz del Castillo que o primeiro comissário da Partida espanhola e governador da Província de Maynas estava enriquecendo por meio do contrabando com os portugueses, acumulando uma fortuna estimada em mais de 200 mil pesos. As rendas remetidas de Quito à Partida de demarcação financiariam o comércio, pois seriam utilizadas para a compra de produtos dos portugueses. Nesse comércio, envolviam-se o primeiro comissário, os oficiais subordinados a ele e outras autoridades no lado espanhol da fronteira, o que contribuiria decisivamente para o sucesso dos contrabandos e o consequente atraso das demarcações. ${ }^{51}$

As autoridades da Audiência de Quito procederam a uma investigação sobre o suposto contrabando praticado pelos oficiais da Partida demarcadora. Alguns dos homens ouvidos (religiosos e soldados que haviam servido em Maynas e na Partida espanhola destacada na Capitania do Rio Negro) confirmaram as acusações lançadas contra o primeiro comissário espanhol. Contudo, não há referências a punições a Francisco Requena ou a outros membros da Partida espanhola. Aparentemente, as acusações e os depoimentos sobre o contrabando não foram convincentes o suficiente para abalar a posição do primeiro comissário. Por outro lado, pode-se especular que fosse mais conveniente para as autoridades da Audiência de Quito não punir os membros da comissão demarcadora: apesar da seriedade das acusações, a tarefa de delimitar a fronteira impunha-se como mais importante, não podendo a Partida ser prejudicada ou atrapalhada na realização de seus objetivos, mesmo que isso significasse a aceitação de certos desvios praticados por seus membros.

O contrabando tornava possível a circulação de produtos em áreas permeadas por tensões políticas, como era o caso dos limites luso-espanhóis ainda não demarcados no extremo norte sul-americano. Com relação à fronteira entre Rio Negro e Maynas no final do

\footnotetext{
${ }^{49}$ APEP, Códice 402, Doc. 22. Ofício de João Batista Mardel a João Pereira Caldas. Ega, 21/07/1784.

50 Rio Negro, AHU, Cx.8, D.340. Ofício do encarregado das demarcações do Rio Negro e Capitão-General, João Pereira Caldas, para o Secretário de Estado da Marinha e Ultramar, Martinho de Melo e Castro. Vila de Barcelos, 02/09/1784.

${ }^{51}$ AGI, Quito, 342, N. 47. Expediente sobre lo representado por D. Ventura Díaz del Castillo, presbítero vecino de Quito, sobre varios puntos que necesitan de remedio en la provincia de Mainas. Quito, junio de 1792.
} 
XVIII, as barreiras enfrentadas pela comissão espanhola para conseguir abastecer-se de víveres certamente eram amenizadas pelas trocas comerciais entretidas entre espanhóis e habitantes da capitania. O contrabando valia-se de teias de relacionamento entre diferentes membros da sociedade, como autoridades, potentados locais e seus dependentes, conferindo proteção à prática do comércio ilícito e assegurando seu controle (e ganhos) a um grupo restrito de sujeitos. ${ }^{52}$

Os limites entre práticas lícitas e ilícitas de comércio, por sua vez, mostravam-se bastante tênues. Nesse sentido, um sujeito que praticava o comércio legal (como o comissário Francisco Requena, que firmara um contrato com comerciantes portugueses) poderia igualmente tomar parte em atividades de contrabando (a julgar pelas acusações lançadas contra o primeiro comissário espanhol). Por fim, não se pretende afirmar, nesse ponto, que as práticas comerciais ilícitas nos limites luso-espanhóis do vale amazônico foram implantadas pelas partidas demarcadoras em fins do século XVIII, tendo em vista a recorrência do contrabando nesse espaço em outros momentos. ${ }^{53}$ Contudo, as interações sustentadas pelas atividades demarcadoras na região dinamizaram os contatos comerciais, lícitos e ilícitos, entre os territórios portugueses e espanhóis confinantes.

\section{A circulação de informações nos limites luso-espanhóis do vale amazônico}

A interação entre as duas partidas demarcadoras alimentou igualmente o fluxo de informações através das fronteiras. Com recorrência, oficiais demarcadores espanhóis e portugueses trocavam entre si ofícios e periódicos, fontes de notícias sobre as conjunturas políticas europeia e americana. A convivência entre os participantes das demarcações possibilitava igualmente a comunicação sobre as transformações em curso nos dois lados da fronteira. Deve-se, além disso, mais uma vez destacar que soldados desertores levavam e traziam importantes informações a respeito dos territórios coloniais limítrofes.

As políticas para as zonas fronteiriças requeriam o acompanhamento das disputas entre os impérios europeus e suas possíveis implicações e ressonâncias nas possessões ultramarinas. Com o Tratado de Santo Ildefonso, as aproximações diplomáticas entre Espanha e Portugal facilitaram o intercâmbio de informações nas fronteiras da América. Oficiais portugueses e espanhóis na região notificavam uns aos outros sobre os mais recentes acontecimentos. O empreendimento das demarcações deveria considerar o contexto político

\footnotetext{
52 Para uma análise sobre as redes sociais e econômicas estabelecidas em áreas de fronteira por meio do contrabando, conferir: GIL, Tiago. Infiéis Transgressores: Elites e contrabandistas nas fronteiras do Rio Grande e do Rio Pardo (1760-1810). Rio de Janeiro: Arquivo Nacional, 2007.

53 Como exemplo, Juan Sebastián Gómez identifica a ocorrência de contrabando na década de 1740, de modo que produtos oriundos do Grão-Pará chegavam à governação de Popayán, com a possibilidade de haver a distribuição dessas mercadorias para outras cidades do Novo Reino de Granada. GómEZ GONZÁLEZ, Juan Sebastián. La Frontera Selvática: Historia de Maynas, siglo XVIII. Tese (Doutorado em Estudos Latino-Americanos). UNAM, México/DF, 2013. p. 172-173. Com relação às trocas comerciais entre portugueses e espanhóis na Amazônia do século XVII, conferir: CARDOSO, Alírio. Maranhão na Monarquia Hispânica: intercâmbios, guerra e navegação nas fronteiras das Índias de Castela (15801655). Tese (Doutorado em História). Universidad de Salamanca, Salamanca, 2012, p. 200-212.
} 
internacional em que se achavam os impérios ibéricos e a inserção dos espaços coloniais americanos nesse quadro. Dessa forma, em 1780, o comandante de Tabatinga, vila no limite entre Rio Negro e Maynas, recebeu do lado espanhol notícias sobre os combates navais na Europa envolvendo Espanha, França e Grã-Bretanha. ${ }^{54}$ Essas informações foram remetidas por Felipe de Arechua y Sarmiento, segundo comissário da Partida espanhola, que também relatou ao comandante português as medidas de defesa nos portos do Caribe espanhol contra as investidas de navios britânicos. ${ }^{55}$

O quadro geral da correlação de forças no vasto mundo atlântico, esboçado por essas informações que chegaram de Maynas a Tabatinga sobre as disputas militares na Europa e América, envolvia as zonas fronteiriças mais interiores do espaço americano, como o vale amazônico. As vitórias dos britânicos (tradicionais aliados da Monarquia lusa) sobre espanhóis (e seus aliados franceses) poderiam ser interpretadas como algo vantajoso para as pretensões territoriais portuguesas no extremo norte. Nesse ponto, especificamente, não se deve perder de vista as desavenças franco-portuguesas na definição de limites na região do Cabo Norte, área extremamente importante pelo acesso à foz do Amazonas e ao arquipélago do Marajó. ${ }^{56}$ Ao mesmo tempo, as informações sobre as medidas defensivas tomadas nas terras hispanoamericanas, relatadas por Arechua y Sarmiento, traziam indícios sobre o poderio bélico dos espanhóis na América do Sul, o que não deixava de ser importante para a formulação da política defensiva dos próprios portugueses no continente.

$\mathrm{Na}$ conjuntura das demarcações ocorreram sérios desafios no Novo Mundo às coroas europeias, o que foi levado em consideração nas interpretações políticas das autoridades locais, a exemplo da revolta de colonos ingleses na América do Norte. Em 1780, João Pereira Caldas avaliou que Espanha, França e Países Baixos (países que possuíam colônias limítrofes com o Estado do Grão-Pará e Rio Negro) não representariam ameaça às áreas fronteiriças do norte da América portuguesa, já que estariam, naquele momento, mais envolvidos na luta independentista dos colonos ingleses, de modo que dificilmente abririam outra frente de conflito no continente americano e, especificamente, no vale amazônico. ${ }^{57}$

Contudo, outra rebelião mereceu maior atenção dos homens envolvidos nas demarcações de limites. Na América andina, grandes sublevações indígenas colocaram em risco o poder espanhol. No Vice-Reino do Peru e no Alto Peru, entre 1780 e 1782, milhares de índios contestaram violentamente as reformas de tributação direcionadas às suas

\footnotetext{
54 APEP, Códice 362, Doc. 11. Ofício de Francisco Vitorino José da Silveira a João Pereira Caldas. Tabatinga, 22/08/1780.

55 APEP, Códice 362, Doc. 12. Ofício de Felipe de Arechua y Sarmiento a Francisco Vitorino José da Silveira. Omáguas, 13/07/1780.

56 Para uma visão geral das disputas de limites franco-portuguesas na região do Cabo Norte ao longo do período colonial, ver: REIS, Arthur Cézar Ferreira. Limites e Demarcações na Amazônia Brasileira: A Fronteira com a Guiana Francesa. Belém: SECULT, 1993.

57 Rio Negro, AHU, Cx.6, D.276. Ofício do encarregado das demarcações do Rio Negro e Capitão-General, João Pereira Caldas, para o Secretário de Estado da Marinha e Ultramar, Martinho de Melo e Castro. Vila de Barcelos, 14/05/1783.
} 
comunidades. ${ }^{58}$ Com relação às fronteiras na América do Sul, as comunicações tecidas localmente entre portugueses e espanhóis possibilitaram que as notícias sobre as sublevações indígenas andinas chegassem à Capitania do Rio Negro. Entre os espanhóis, havia o temor de que os índios sublevados fugissem para a América portuguesa, ou mesmo que obtivessem apoio de portugueses em sua luta. Por isso, Francisco Requena informou os militares portugueses no Rio Negro sobre as revoltas nos Andes, solicitando a prisão dos sublevados que, por ventura, ingressassem no lado português da fronteira. Ainda segundo Requena, os índios rebeldes poderiam procurar os portugueses para conseguir víveres e munições a fim de sustentar a guerra contra os espanhóis. ${ }^{59}$

As notícias sobre as sublevações andinas foram recebidas com desconfiança no lado português da fronteira. Em 1782, o governador da Capitania do Mato Grosso recebeu da vizinha província espanhola de Santa Cruz informes sobre as guerras dos índios no Alto Peru, os quais ameaçavam, em suas palavras, "sacudir o jugo espanhol". Contudo, o governador do Mato Grosso, escrevendo aos demarcadores portugueses no Rio Negro, revelou desconfiar de que, por trás das notícias sobre a guerra contra os índios, existissem outros interesses dos espanhóis. Para o governador, os espanhóis possivelmente se utilizavam da sublevação indígena para disfarçar seus planos militares de invadir as fronteiras da América portuguesa. Os levantes indígenas seriam utilizados pelos espanhóis como justificativa para ampliar sua presença militar nas imediações com a América portuguesa, tornando possível uma grande ofensiva contra as terras luso-americanas. ${ }^{60}$ Nesse sentido, o fluxo para o território lusoamericano de notícias sobre as revoltas indígenas nos Andes revelava-se importante para que os vassalos portugueses elaborassem suas análises quanto às possíveis consequências desse evento para suas fronteiras.

A circulação de informações também poderia ser concretizada através da troca de gazetas entre os membros das partidas de demarcação. A remessa de gazetas era uma demonstração de cordialidade entre as partes, mas principalmente um recurso de instrução sobre o contexto político internacional e suas possíveis implicações no território americano. Assim, no dia 7 de outubro de 1789, o oficial da Partida portuguesa, Henrique João Wilckens, foi oficialmente comunicado pelo primeiro comissário Francisco Requena da morte do monarca espanhol, Carlos III (ocorrida no dia 14 de dezembro de 1788), e da ascensão ao trono de Carlos IV. Para informar a Partida lusa, Requena entregou a Wilckens uma coleção de gazetas espanholas, nas quais constavam notícias sobre a sucessão no trono da Espanha. A demora do comissário espanhol em informar a morte do rei certamente se devia não apenas às dificuldades de contato da fronteira com outras partes do império e a consequente demora na circulação de ofícios e periódicos. Além desse fator, os oficiais demarcadores deveriam ter

58 O'PHELAN GODOY, Scarlett. Un Siglo de Rebeliones Anticoloniales: Perú y Bolivia, 1700-1783. Lima: PUCP, 2012; WALKER, Charles F. The Tupac Amaru Rebellion. Cambridge, London: The Belknap Press of Harvard University Press, 2014.

59 APEP, Códice 375, Doc. 42. Ofício de Francisco Requena a João Pereira Caldas. Tabatinga, 06/05/1781.

60 Mato Grosso, AHU. Ofício do Governador e Capitão-General do Mato Grosso, Luis de Albuquerque de Melo Pereira e Cárceres, para o secretário de Estado da Marinha e Ultramar, Martinho de Melo e Castro. Vila Bela, 25/07/1782. 
cautela na divulgação de algumas novidades, principalmente em se tratando de informações consideradas estratégicas, como a ascensão de um novo rei. No caso em questão, antes de ser comunicado por Requena e receber as gazetas espanholas, o oficial português já soubera da morte de Carlos III através de "canoas vindas da confinante Província de Maynas", ${ }^{61}$ ou seja, tratava-se de uma notícia já conhecida naquela fronteira, mas que ainda não havia sido oficialmente divulgada pelos demarcadores espanhóis.

Os oficiais demarcadores também procuraram acompanhar as notícias sobre os acontecimentos que estavam se desenrolando na França a partir de 1789. Mais uma vez, os periódicos foram um dos mecanismos de divulgação. ${ }^{62}$ As gazetas castelhanas e portuguesas que chegavam às mãos dos demarcadores, e que eram trocadas e comentadas pelos participantes das duas partidas, traziam relatos sobre a crise da monarquia francesa e as transformações na França e na Europa decorrentes do processo revolucionário. Escrevendo ao primeiro comissário português em 1789, Henrique João Wilckens afirmou ter tido conhecimento sobre as "novidades importantes" da França através de gazetas espanholas que Ihe foram enviadas pela Partida demarcadora castelhana. ${ }^{63}$ No ano seguinte, Wilckens ofereceu ao primeiro comissário espanhol gazetas portuguesas, "algumas mais modernas," e que contavam "miudamente o levantamento de Paris". ${ }^{64}$

A demanda por informações a respeito dos acontecimentos na França obedecia à necessidade das autoridades ibéricas na fronteira de fundamentar seus planejamentos no conhecimento e avaliação das transformações políticas em curso. No caso da Revolução Francesa, seus sucessos apontavam com veemência para a crise do Absolutismo e do Antigo Regime, alterando igualmente o equilíbrio de forças na Europa, o que traria consequências para as zonas coloniais. ${ }^{65} \mathrm{E}$ de modo mais preciso, não se pode perder de vista as alterações que a grave crise francesa traria para a aliança com a Espanha, o que repercutiria inevitavelmente na balança dos poderes imperiais europeus e na condução de suas políticas para o mundo ultramarino. Dentre essas políticas, é claro, incluía-se a demarcação dos limites luso-espanhóis na América Meridional.

As notícias que circulavam entre os membros das comissões demarcadoras não diziam respeito apenas às conjunturas e aos desafios enfrentados pelos impérios ultramarinos. Era também necessário coletar informações sobre as possessões coloniais limítrofes, algo indispensável para os planejamentos militares. Para os demarcadores portugueses na fronteira norte, era importante obter informações sobre a América espanhola. Essas informações

\footnotetext{
61 PCDL, Arquivo Ponte Ribeiro, A-36: Correspondência de Diversos com o Governo (1762-1803). Ofício de Henrique João Wilckens a Manoel da Gama Lobo d'Almada. Ega, 13/10/1789.

62 ROSAS LAURO, Claudia. Del Trono a la Guillotina: El Impacto de la Revolución Francesa en el Perú (1789-1808). Lima: IFEA, Fondo Editorial de la PUCP, Embajada de Francia en el Perú, 2006. p. 53-65 e p. $99-106$.

63 APEP, Códice 461, Doc. 38. Ofício de Henrique João Wickens a Manoel da Gama Lobo d'Almada. Barcelos, 22/12/1789.

64 APEP, Códice 461, Doc. 66. Ofício de Henrique João Wilckens a Manoel da Gama Lobo d'Almada. Barcelos, 14/05/1790.

65 JANCSÓ, István. Na Bahia, Contra o Império. História do ensaio de sedição de 1798. São Paulo: HUCITEC; Salvador: EDUFBA, 1996. p. 164.
} 
embasavam os planos de defesa da Capitania do Rio Negro e as estratégias ofensivas contra os espanhóis. A partir do convívio com índios e soldados espanhóis empregados na demarcação, os portugueses indagavam a respeito das terras hispano-americanas vizinhas. Essa operação de coleta e sistematização de informações estratégicas foi realizada pelo comandante de Tabatinga, o qual havia se inteirado a respeito das "fronteiras províncias espanholas" através de "indagações" dirigidas a soldados espanhóis que passaram por sua vila durante as demarcações. Dessa forma, o comandante se encarregou de indagar, "com toda a cautela e segredo", os membros da Partida espanhola sobre Maynas e suas comunicações com outras províncias, alcançando assim informações sobre o governo político, os habitantes e a economia do território vizinho. ${ }^{66}$

Além do mais, os contatos diários entre participantes das duas partidas poderiam fornecer dados sobre a movimentação de tropas e o estado político nas colônias americanas. Em 1784, um soldado espanhol contou aos portugueses em Tabatinga que 8 mil soldados tinham vindo da Espanha para servir no Panamá e em Lima. Em outra oportunidade, o tesoureiro da Partida espanhola confidenciou a um membro da Partida portuguesa ter ouvido boatos sobre a possibilidade de guerra contra Portugal, caso as demarcações de limites na América não fossem finalizadas. ${ }^{67}$ Informações como essas, coletadas cotidianamente, contribuíam para que portugueses e espanhóis formassem uma "imagem," ainda que parcial e fragmentária, sobre o território colonial vizinho e os desdobramentos políticos dos trabalhos de demarcação.

A política de demarcação de limites demandava e possibilitava o fluxo de informações na fronteira hispano-portuguesa da América. A circulação de informações políticas valia-se não apenas das comunicações oficiais, como também das teias de relação vigentes nas zonas limítrofes, ligando sujeitos dos dois lados dos domínios ibéricos. Diferentes fontes (como ofícios, gazetas, conversas mantidas com soldados e índios que cruzavam a fronteira) traziam dados sobre a política internacional e o estado dos territórios contíguos, compondo o acervo de informações a partir do qual as autoridades ibéricas interpretavam a conjuntura e seus possíveis desdobramentos. A maneira como ocorria a circulação de informações na fronteira luso-espanhola (agregando diferentes fontes e meios de divulgação, resultando em leituras múltiplas sobre um mesmo fato) não diferia substancialmente do que ocorria em outras sociedades de Antigo Regime, consistindo parte importante da forma como os sujeitos da época construíam suas interpretações políticas. ${ }^{68}$

\footnotetext{
66 Rio Negro, AHU, Cx.13, D.514. Ofício do encarregado das demarcações do Rio Negro e CapitãoGeneral, João Pereira Caldas, para o secretário de Estado da Marinha e Ultramar, Martinho de Melo e Castro. Vila de Barcelos, 22/04/1788.

${ }^{67}$ Rio Negro, AHU, Cx.8, D.330. Ofício do encarregado das demarcações do Rio Negro e Capitão-General, João Pereira Caldas, para o secretário de Estado da Marinha e Ultramar, Martinho de Melo e Castro. Vila de Barcelos, 30/07/1784.

68 Sobre isso, Robert Darnton sustenta que "as mídias do Antigo Regime eram misturadas. Elas transmitiam um amálgama de sobreposições, interpenetrando mensagens faladas, escritas, impressas, desenhadas e cantadas". DARNTON, Robert. Uma precoce sociedade da informação: As notícias e a mídia em Paris no século XVIII. Varia Historia, v. 25, 2001, (9-51).
} 
Figura 2

Rios percorridos pelas comissões demarcadoras luso-espanholas nos anos de 1781-1782

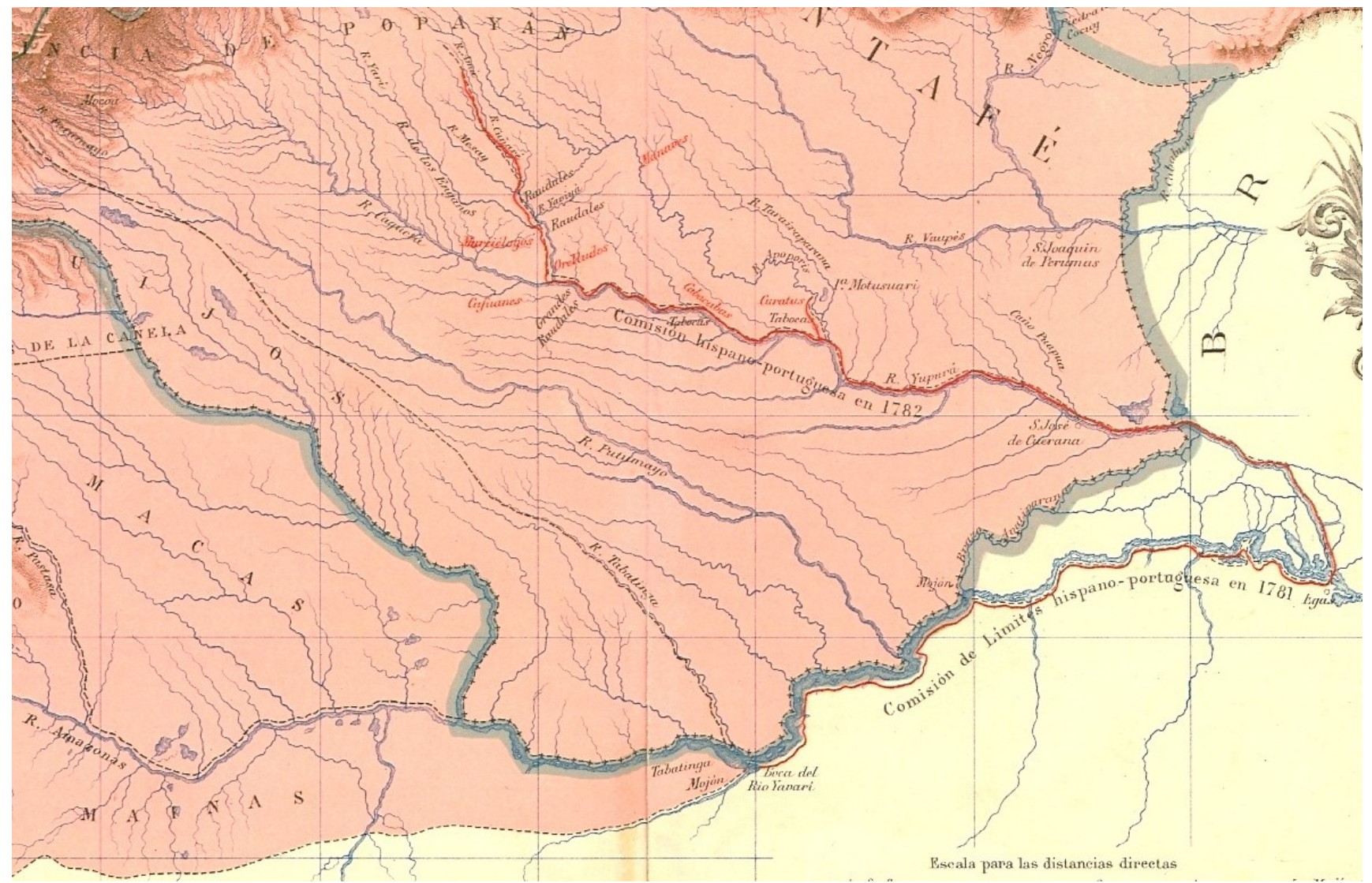

Carta del Virreinato de Santa Fé y de la Capitanía General de Venezuela. In: Atlas geográfico e histórico de la República de Colombia, 1890. Disponível em:

http://upload.wikimedia.org/wikipedia/commons/9/9c/Virreinato_de_Santaf\%C3\%A9_y_Capitan\%C3\%A Da_General_de_Venezuela.jpg. ${ }^{69}$

\section{Considerações finais}

Os tratados assinados pelas coroas espanhola e portuguesa nos anos finais da década de 1770 sinalizavam as expectativas quanto à definição das disputas territoriais ultramarinas e a manutenção de relações diplomáticas menos conflitivas entre os dois impérios. No entanto, o enfrentamento e a possibilidade de novas guerras opondo lusos e espanhóis não foram possibilidades descartadas nos planejamentos geopolíticos nessa nova conjuntura. No que diz respeito às demarcações de limites, essas questões se faziam presentes nos contatos travados entre as autoridades demarcadoras.

As interações na fronteira americana concretizavam, no plano local, as relações sustentadas entre Portugal e Espanha nas décadas finais do século XVIII. Tratava-se de relações permeadas por tensões e auxílios, aproximações e desconfianças, alianças e competições. O espaço da fronteira americana não poderia deixar de refletir essas variações do conjunto do qual faziam parte (os impérios espanhol e português). Contudo, ao mesmo tempo

69 Nesse mapa da última década do século XIX, as linhas em vermelho representam duas rotas importantes dos trabalhos conjuntos de demarcação de limites na década de 1780, destacando-se a vila de Ega como ponto de reunião das partidas luso-espanholas estacionadas na Capitania do Rio Negro. 
as interações na fronteira concorreram para forjar experiências a partir das quais as autoridades ibéricas planejaram suas práticas políticas. Por meio dos trabalhos de demarcação, os representantes das duas coroas ampliaram seu conhecimento sobre seus territórios, como também a respeito dos territórios confinantes, e puderam formular suas expectativas e suas medidas para as regiões limítrofes americanas.

Por outro lado, as demarcações, ao mesmo tempo que buscavam ampliar o controle sobre as áreas confinantes dos impérios ibéricos na América, alimentavam as interações e circulações nessas partes do continente. A longa permanência da Partida espanhola na Capitania do Rio Negro, a realização de trabalhos conjuntos envolvendo portugueses e espanhóis nas demarcações, além dos contatos cotidianamente tecidos com os demais habitantes locais, criavam situações que viabilizavam a circulação de pessoas, mercadorias e informações. Dessa forma, as partidas demarcadoras, ao colocar em prática os trabalhos de efetivação de uma fronteira-linha (isto é, uma delimitação espacial que respondesse às necessidades de controle dos poderes coloniais sobre o território), potencializavam as dinâmicas próprias de uma fronteira-zona (entendida como espaço de trocas comerciais, culturais e humanas). ${ }^{70}$ As demarcações, portanto, se valiam das circulações fronteiriças ibero-americanas, e mesmo as impulsionavam, para que pudessem atuar na região.

Carlos Augusto Bastos: Professor de História da Amazônia na Universidade Federal do Pará (UFPA-Campus de Ananindeua). Doutor em História Social pela USP, realiza pesquisas sobre fronteiras na Amazônia dos séculos XVIII-XIX.

70 CHESNEAUX, Jean. "L'insertion de I'histoire dans l'espace: la géopolitique." Du passe faison table rase? Paris: François Maspero, 1976. p. 157-167. 